University of Nebraska - Lincoln

DigitalCommons@University of Nebraska - Lincoln

\title{
Uranium in Framboidal Pyrite from a Naturally Bioreduced Alluvial Sediment
}

Nikolla P. Qafoku

Pacific Northwest National Laboratory, nik.qafoku@pnl.gov

Ravi K. Kukkadapu

Pacific Northwest National Laboratory, ravi.kukkadapu@pnl.gov

James P. McKinley

Pacific Northwest National Laboratory

Bruce W, Arey

Pacific Northwest National Laboratory

Shelly D. Kelly

Argonne National Laboratory

See next page for additional authors

Follow this and additional works at: https://digitalcommons.unl.edu/usdoepub

Part of the Bioresource and Agricultural Engineering Commons

Qafoku, Nikolla P.; Kukkadapu, Ravi K.; McKinley, James P.; Arey, Bruce W; Kelly, Shelly D.; Wang, Chongmin; Resch, Charles T.; and Long, Philip E., "Uranium in Framboidal Pyrite from a Naturally Bioreduced Alluvial Sediment" (2009). US Department of Energy Publications. 152.

https://digitalcommons.unl.edu/usdoepub/152

This Article is brought to you for free and open access by the U.S. Department of Energy at DigitalCommons@University of Nebraska - Lincoln. It has been accepted for inclusion in US Department of Energy Publications by an authorized administrator of DigitalCommons@University of Nebraska - Lincoln. 


\section{Authors}

Nikolla P. Qafoku; Ravi K. Kukkadapu; James P. McKinley; Bruce W, Arey; Shelly D. Kelly; Chongmin Wang; Charles T. Resch; and Philip E. Long 


\section{Uranium in Framboidal Pyrite from a Naturally Bioreduced Alluvial Sediment}

\author{
NIKOLLA P. QAFOKU, ${ }^{*, \dagger}$ \\ RAVI K. KUKKADAPU, JAMES P. MCKINLEY, ${ }^{\dagger}$ \\ BRUCE W. AREY, ${ }^{\dagger}$ SHELLY D. KELLY, ${ }^{\ddagger}, \$$ \\ CHONGMIN WANG ${ }^{\dagger}$ CHARLES T. RESCH ${ }^{\dagger}$ \\ AND PHILIP E. LONG ${ }^{\dagger}$ \\ Pacific Northwest National Laboratory, Richland, Washington \\ 99352, and Argonne National Laboratory, \\ Argonne, Illinois 60439
}

Received July 14, 2009. Revised manuscript received September 23, 2009. Accepted September 30, 2009.

Samples of a naturally bioreduced, U-contaminated alluvial sediment were characterized with various microscopic and spectroscopic techniques and wet chemical extraction methods. The objective was to investigate $\mathrm{U}$ association and interaction with minerals of the sediment. Bioreduced sediment comprises $\sim 10 \%$ of an alluvial aquifer adjacent to the Colorado River, in Rifle, $\mathrm{CO}$, that was the site of a former $\mathrm{U}$ milling operation. Past and ongoing research has demonstrated that bioreduced sediment is elevated in solid-associated $\mathrm{U}$, total organic carbon, and acid-volatile sulfide, and depleted in bioavailable $\mathrm{Fe}(\mathrm{III})$ confirming that sulfate and $\mathrm{Fe}(\mathrm{III})$ reduction have occurred naturally in the sediment. SEM/EDS analyses demonstrated that framboidal pyrites $\left(\mathrm{FeS}_{2}\right)$ of different sizes $(\sim 10-20 \mu \mathrm{m}$ in diameter), and of various microcrystal morphology, degree of surface weathering, and internal porosity were abundant in the $<53 \mu \mathrm{m}$ fraction (silt + clay) of the sediment and absent in adjacent sediments that were not bioreduced. SEM-EMPA, XRF, EXAFS, and XANES measurements showed elevated U was present in framboidal pyrite as both $\mathrm{U}(\mathrm{VI})$ and $\mathrm{U}(\mathrm{IV})$. This result indicates that $\mathrm{U}$ may be sequestered in situ under conditions of microbially driven sulfate reduction and pyrite formation. Conversely, such pyrites in alluvial sediments provide a long-term source of $\mathrm{U}$ under conditions of slow oxidation, contributing to the persistence of $\mathrm{U}$ of some $\mathrm{U}$ plumes. These results may also help in developing remedial measures for U-contaminated aquifers.

\section{Introduction}

Redox-sensitive radionuclides, such as uranium (U), whose mobility and solubility changes dramatically with redox status, e.g., highly mobile hexavalent $\mathrm{U}[\mathrm{U}(\mathrm{VI})]$ and nearly immobile tetravalent $U$ [U(IV)], are common in many contaminated Department of Energy (DOE) sites (1). Field remediation experiments are currently underway at the Integrated Field Research Challenge (IFRC) at the DOE Rifle site in Colorado to immobilize $U$ in groundwater by stimulating the activity of U(VI)-reducing microorganisms

* Corresponding author phone: (509) 371-6089; fax: (509) 3756954; e-mail: nik.qafoku@pnl.gov.

${ }^{\dagger}$ Pacific Northwest National Laboratory.

* Argonne National Laboratory.

${ }^{\S}$ Current affiliation: EXAFS Analysis, Bolingbrook, IL 60440. via amendment of the subsurface with an electron donor $(2,3)$. The remedial approach is thus to form insoluble U(IV) phases (4-6) under Fe- and/or sulfate-reducing conditions (7). Experimental results from Rifle have demonstrated that aqueous U(VI) removal continued long after acetate amendment was terminated, suggesting the importance of processes occurring after direct microbial reduction of $U$ under Fereducing conditions. Most likely, multiple U(VI) attenuation mechanisms are operational in the postamendment bioreduced geochemical system (e.g., adsorption to microbial or inorganic surfaces (8), or adsorption to minerals followed by abiotic reduction (9)).

Field sampling and observations from the IFRC at Rifle have demonstrated that naturally bioreduced zones are present in the shallow unconsolidated alluvial aquifer at the site $(10)$, comprising $\sim 10 \%$ of the aquifer volume. In spite of the fact that the aquifer at the Rifle IFRC is only $\sim 3$ $\mathrm{m}$ thick and has a maximum depth of 7 to $9 \mathrm{~m}$, naturally bioreduced zones persist due to high concentrations of natural organic carbon in the form of roots, twigs, and other plant materials (10). Given that the groundwater at Rifle contains significant amounts of sulfate $(\sim 6-9 \mathrm{mM})$ and the naturally bioreduced zones typically contain substantially more $U$ and acid-volatile sulfide than the sediments that are not bioreduced (10), a better understanding of the Fe-sulfide minerals and their interaction with $\mathrm{U}(\mathrm{VI})$ is needed to (a) predict the long-term fate of contaminant $U$ and (b) design new and more effective remediation strategies, in addition to the ones that are currently underway at the Rifle IFRC. This is particularly important because the U plume at the Rifle IFRC is not naturally attenuating at the rate predicted. Instead it is relatively stable, exhibiting season changes in $\mathrm{U}$ concentration but not a consistent downward trend in over the past decade (seehttp://gems.lm.doe.gov/imf/imfjsp?site= rifleoldprocessing\&title $=$ Rifle + Old $,+\mathrm{CO},+$ Processing + Site for $U$ concentration data for the site).

U(VI) uptake by soils and sediments has been in the center of many publications (ref 11 and references therein). In particular, Fe-bearing minerals such as ferrihydrite, goethite, hematite, and magnetite, which are ubiquitous in soils and sediments, show great affinity for aqueous U(VI) species (12-25). However, in the naturally or artificially bioreduced sediments Fe sulfides such as Fe monosulfide FeS (mackinawite), greigite $\left(\mathrm{Fe}_{3} \mathrm{~S}_{4}\right)$, euhedral pyrite $\left(\mathrm{FeS}_{2}\right)$ and framboidal pyrite may also be present. Past laboratory research with pyrite crystals demonstrated that $\mathrm{U}(\mathrm{VI})$ adsorption and partial reduction occur on the surfaces of both unweathered and weathered pyrites (26-29). However, there are no such studies with naturally occurring Fe-sulfides. High concentrations of $U(V I)$ in pyrite, including framboidal pyrite in naturally bioreduced sediments have not been previously reported.

Detection of relatively high concentrations of U, Fe, and $\mathrm{S}$ in naturally bioreduced sediments at Rifle (10) suggests the potential importance of Fe-sulfides to $U$ fate and transport. For this reason, and because there were few previous studies on U interaction with natural Fe sulfides, we performed an array of microscopic and spectroscopic studies combined with wet chemical extractions, to assess the presence of $\mathrm{Fe}$ sulfides in the naturally bioreduced sediment, and examine their role in $U$ attenuation (particularly, framboidal pyrite). In this paper, we show that framboidal pyrites are present in the naturally bioreduced sediment and that they contain high concentration of $U$, possibly decreasing its mobility, but also serving as potential long-term sources of $\mathrm{U}(\mathrm{VI})$ during later oxidation of pyrite. 
The insights gained from this study have enhanced our understanding of the long-term persistence of $U$ in groundwater in alluvial aquifers.

\section{Materials and Methods}

Sediment Material. Several cores were drilled in an area that included naturally occurring U(VI) bioreduction at Rifle, $\mathrm{CO}$, in preparation for the 2007 biostimulation experiment (Supporting Information (SI) Figure S1). Sediment materials were obtained at different depths within vadose and saturated zones of the subsurface. The cores represented a cross section of sediment conditions that ranged from typical aquifer (minimally reduced) to highly bioreduced (within the saturated zone). For this study we focused on a naturally bioreduced sediment sample (D08-16) collected at a depth of 16 feet $(\sim 5 \mathrm{~m})$ below ground surface. The context of this sample including the geometry and characteristics of the bioreduced sediments are described elsewhere (9).

Size-Fraction Separation, Extractions, and Sediment Characterization. Sediments were stored at $-40{ }^{\circ} \mathrm{C}$ and sediment subsamples were either air-dried on laboratory bench tops for size-fraction separation analyses and chemical extractions, or dried inside an anoxic chamber and used for microscopic and spectroscopic studies as it is described below. Seven size fractions were separated from the $<2 \mathrm{~mm}$ material of different sediment samples collected at Rifle. The $<53 \mu \mathrm{m}$ fraction separated from the naturally bioreduced sediment, which is the focus of this paper, was characterized with the methods described below.

Scanning Electron Microscopy (SEM) (Combined with Focused Ion Beam (FIB), Energy Dispersive Spectrometry (EDS), and Electron Microprobe Analysis (EMPA)), High Resolution Transmission Electron Microscopy (HRTEM) (combined with Selected Area Electron Diffraction (SAED)), Measurements. For the SEM and EDS measurements, polished sections and individual clasts of the $<53 \mu \mathrm{m}$ fraction were carbon coated to make them electrically conductive. They were examined using JEOL 6340f SEM. Images were then collected using a backscattered electron detector for atomic number contrast. A JEOL model 8200 EMPA with a detection limit of $\sim 100 \mu \mathrm{g} \mathrm{g}^{-1}$ and optical resolution of 50 $\mathrm{nm}$, was used to take additional measurements including quantification of $U$ concentration in pyrite. High resolution TEM analysis was carried out on a Jeol JEM 2010 microscope fitted with $\mathrm{L} \mathrm{LaB}_{6}$ filament and an acceleration voltage of 200 $\mathrm{kV}$. A fibbed thin section (framboid shown in SI Figure S8) was used for TEM work. The point-to-point resolution of the microscope was $0.194 \mathrm{~nm}$. All the images were recorded using a $1 \times 1 \mathrm{kCCD}$ camera and processed using Digital Micrograph (Gatan, U.S.). Lattice plane space was measured using selected area electron diffraction (SAED) method. The camera constant of the microscope was calibrated using evaporated Al polycrystalline thin film, which yields an overall measurement accuracy of $1.4 \%$. The experimentally obtained electron diffraction pattern was also matched with calculated diffraction patterns. The calculation was carried using the Desktop Microscopist code.

Mössbauer Spectroscopy. Mössbauer spectra were collected in the $<53 \mu \mathrm{m}$ fraction using a $50 \mathrm{mCi}$ (initial strength) ${ }^{57} \mathrm{Co} / \mathrm{Rh}$ source. The velocity transducer MVT-1000 (WissEL) was operated in a constant acceleration mode $(23 \mathrm{~Hz}, \pm 12$ $\mathrm{mm} / \mathrm{s})$. An $\mathrm{Ar}-\mathrm{Kr}$ proportional counter was used to detect the radiation transmitted through the holder, and the counts were stored in a multichannel scalar (MCS) as a function of energy (transducer velocity) using a 1024 channel analyzer. Data were folded to 512 channels to give a flat background and a zero-velocity position corresponding to the center shift (CS) of a metal Fe foil at room temperature (RT). Calibration spectra were obtained with a $25 \mu \mathrm{m}$ thick $\mathrm{Fe}(\mathrm{m})$ foil (Amersham, England) placed in the same position as the samples to minimize any errors due to changes in geometry. A closed-cycle cryostat (ARS, Allentown, PA) was employed for below RT measurements. The Mössbauer data were modeled with the Recoil software (University of Ottawa, Canada) using a Voight-based structural fitting routine. The coefficient of variation of the spectral areas of the individual sites generally ranged between 1 and $2 \%$ of the fitted values.

X-ray Fluorescence (XRF) and X-ray Absorption Spectroscopy (XAS). The X-ray fluorescence (XRF) and X-ray absorption spectroscopy (XAS) spectra were collected at MRCAT 10-ID (30) at the Advanced Photon Source. The third harmonic of the undulator insertion device was slightly tapered by $0.1 \mathrm{KeV}$. X-ray harmonics were removed with a Rh coated mirror. The incident $\mathrm{X}$-ray intensity was monitored using a nitrogen filled ionization chamber and the X-ray fluorescence was monitored using a 13 element Ge detector with XIA electronics. A U(VI) standard reference sample was measured using scattered radiation (31) using a hydrogen uranyl phosphate standard. The peak of the first derivative of the uranyl standard was calibrated to $17171 \mathrm{eV}$. The XANES spectra from the sample were aligned to the standard collected simultaneously with the sample. The spectra were then compared to the U(VI) standard and a natural uraninite as the U(IV) standard. Polished $<53 \mu \mathrm{m}$ samples were placed in the X-ray beam at $45^{\circ}$ with respect to the incident X-ray beam direction. Kirkpatrick-Baez mirrors were used to focus the X-ray beam to $40 \mu \mathrm{m}$ vertically and $30 \mu \mathrm{m}$ effective on the sample horizontally (taking into account the $45^{\circ}$ angle) for the initial large X-ray fluorescence maps of the sample and then to $20 \mu \mathrm{m}$ vertically by $20 \mu \mathrm{m}$ effective horizontally for the X-ray absorption spectra. The incident X-ray energy of $17200 \mathrm{eV}$ was used for the XRF maps to excite U within the sample. Finer scale maps were collected at points of interest. The XAS spectra were collected in step scanning mode and processed using IFEFFIT (32) and ATHENA (33) software interface.

\section{Results and Discussion}

Sediment Mineralogy. The mineralogy of the $<2 \mathrm{~mm}$ size fraction consisted of quartz (52\%), plagioclase (24\%), Kfeldspar (12\%), mica (8\%), and calcite (3\%) (10). Illite (68\%), smectite $(22 \%)$, chlorite $(5 \%)$, and kaolinite $(5 \%)$ were the dominant minerals in the clay fraction $(<2 \mu \mathrm{m})(10)$. The presence of pyrite was confirmed with XRD (SI Figure S2). However, neither mackinawite and greigite nor Fe oxides were detected with XRD. Results from zero-field Mössbauer spectroscopy analyses unambiguously indicated that in the $<53 \mu \mathrm{m}$ fraction various Fe-oxides (hematite (14\%), magnetite $(10 \%)$ and goethite $(4 \%))$ and clay Fe(II) $(21 \%)$ were present (Figure 1). However, peaks due to clay Fe(III) and low spin Fe(II) (e.g., pyrite and mackinawite), which comprised a spectral area of $52 \%$, are not resolved from each other (data not shown). Greigite, a metastable product relative to pyrite, and siderite (a compound expected to precipitate under the field groundwater conditions) were not detected. No pyrite or other sulfides were detected in any size fraction from sediment samples collected outside of the naturally bioreduced zone.

Framboidal Pyrite Occurrence. Results from $0.5 \mathrm{~N} \mathrm{HNO}_{3}$ extractions indicated that the $<53 \mu \mathrm{m}$ fraction of the naturally bioreduced sediment had the greatest $\mathrm{U}, \mathrm{Fe}$, and $\mathrm{S}$ contents (SI Figures S3 and S4). For this reason, samples from this size fraction were used for further detailed characterization studies. SEM micrographs and EDS analyses demonstrated that pyrite and framboidal pyrite were abundant in the $<53$ $\mu \mathrm{m}$ size fraction of the sediment (Figure 2 and SI Figure S5 and S6). The chemical composition of unweathered framboid microcrystals was uniform and the $\mathrm{S} / \mathrm{Fe}$ atomic percent ratio was close to 2 confirming that the framboids were composed of chemically identical individual pyrite $\left(\mathrm{FeS}_{2}\right)$ microcrystals 


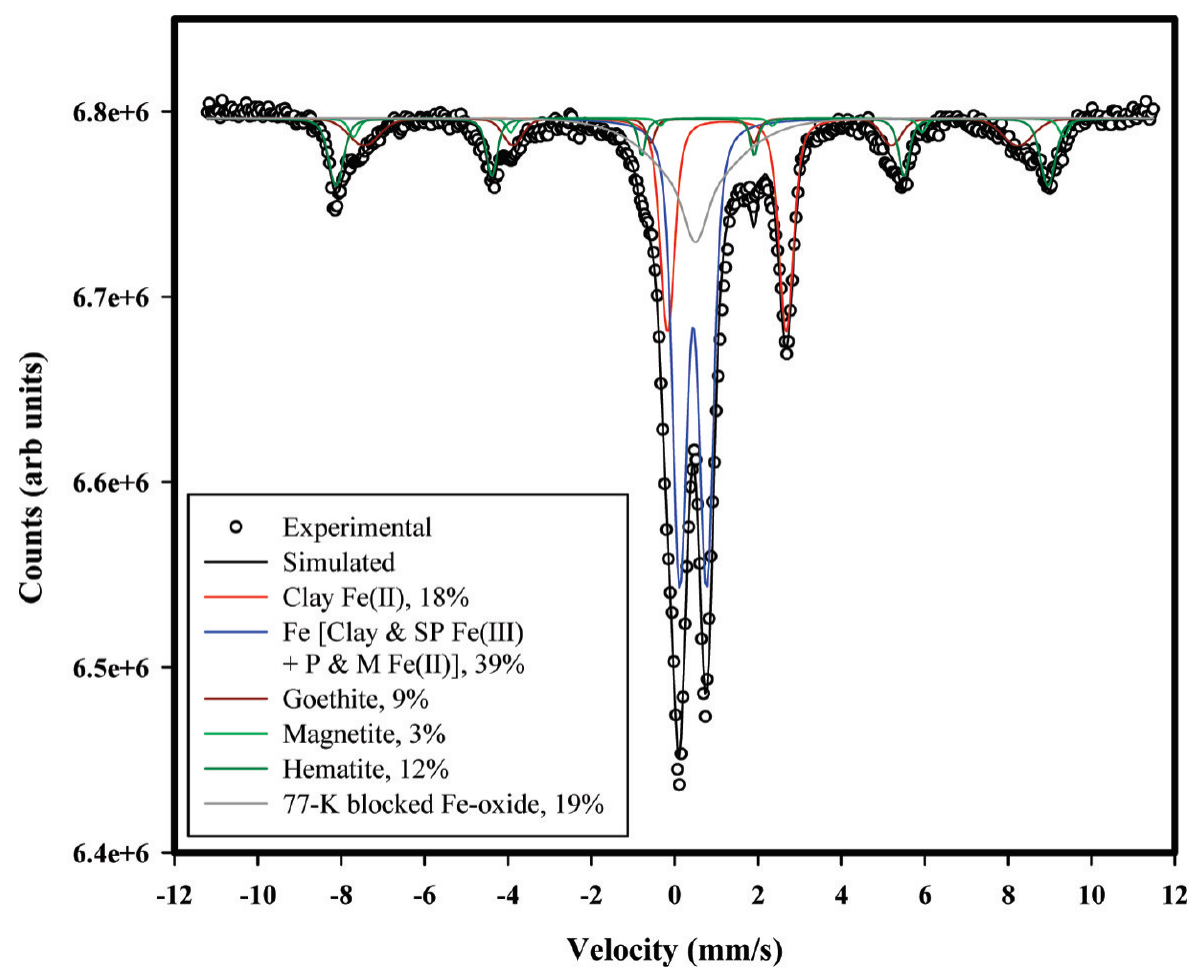

FIGURE 1. Results from the Mössbauer spectroscopy analyses. The abundances of Fe solid phases in the $<53 \mu \mathrm{m}$ fraction of the naturally bioreduced sediment are included in the associated table.
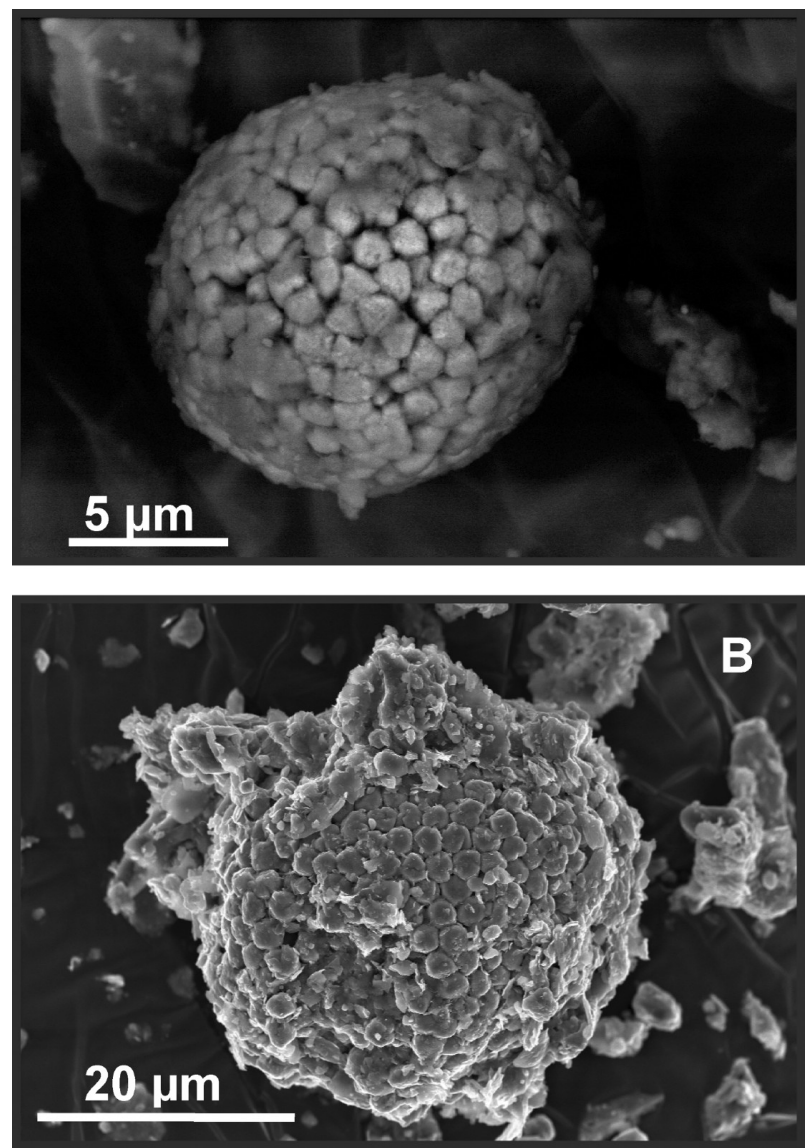

FIGURE 2. Micrographs (secondary electron images) of two representative framboidal pyrites found in the $<53 \mu \mathrm{m}$ fraction of the naturally bioreduced sediment, including a spheroidal (A) and an irregular (B) framboidal structure.

(SI Figure S5). SEM-FIB analyses combined with HRTEM and SAED confirmed that the framboid microcrystals were single-crystals and that the rim $(<0.1 \mu \mathrm{m}$ thickness $)$ had different chemical composition than the bulk material (SI Figure S7), possibly reflecting alteration of the surface by recent groundwater, e.g., slightly oxidative weathering.

EMPA Analyses. The $<53 \mu \mathrm{m}$ size fraction of the naturally bioreduced sediment was inspected with SEM and EMPA to locate zones within the sediments matrix with high $U$ concentration. The EMPA results show that $U$ association with Si-containing minerals (i.e., clays), was negligible (below detection). However, $U$ occurs in relatively high concentration in framboidal pyrite (Figure 3 and SI Figure S8 and S9) and magnetite (data not shown). EMPA measurements of U concentration in the two framboidal pyrites depicted in Figure 3 indicate that the framboid containing more $\mathrm{O}$ had more $\mathrm{U}(\sim 200 \mathrm{ppm})$ than the one with stoichiometric $\mathrm{FeS}_{2}(<100$ ppm).

Weathering (oxidation) of the pyrite surface may occur following the overall reactions (29):

$$
4 \mathrm{FeS}_{2}+14 \mathrm{H}_{2} \mathrm{O}+15 \mathrm{O}_{2} \rightarrow 4 \mathrm{Fe}(\mathrm{OH})_{3}+8 \mathrm{SO}_{4}^{2-}+16 \mathrm{H}_{(\mathrm{aq})}^{+}
$$

As a result of the formation of secondary weathering products (such as Fe(III) oxides) that may partially or fully coat framboid/microcrystal surface, the surface sorption properties of framboids may change (since Fe(III) oxides are good $\mathrm{U}(\mathrm{VI})$ sorbents (19)). Apparently, weathering products are present in the framboids of the naturally bioreduced sediment (SI Figure S10), although the presence of residual biofilms cannot be excluded (some framboid pyrite were partly covered with what appears to be filamentous biofilm, which in some cases connected pyrite microcrystals). The chemical compositions of the two framboidal pyrites of Figure $3 \mathrm{~A}$ clearly show pyrite oxidation and weathering of one of the framboids. The two framboids have similar Fe concentration (33\%) but different S concentrations (46 and 66\%) and $\mathrm{O}$ concentrations (19 and $0 \%$ ), indicating the formation of $\mathrm{Fe}$ oxides as weathering products in the framboid with high $\mathrm{O}$. Weathering is further evident from differences in morphology of microcrystals between unweathered and weathered pyrites 


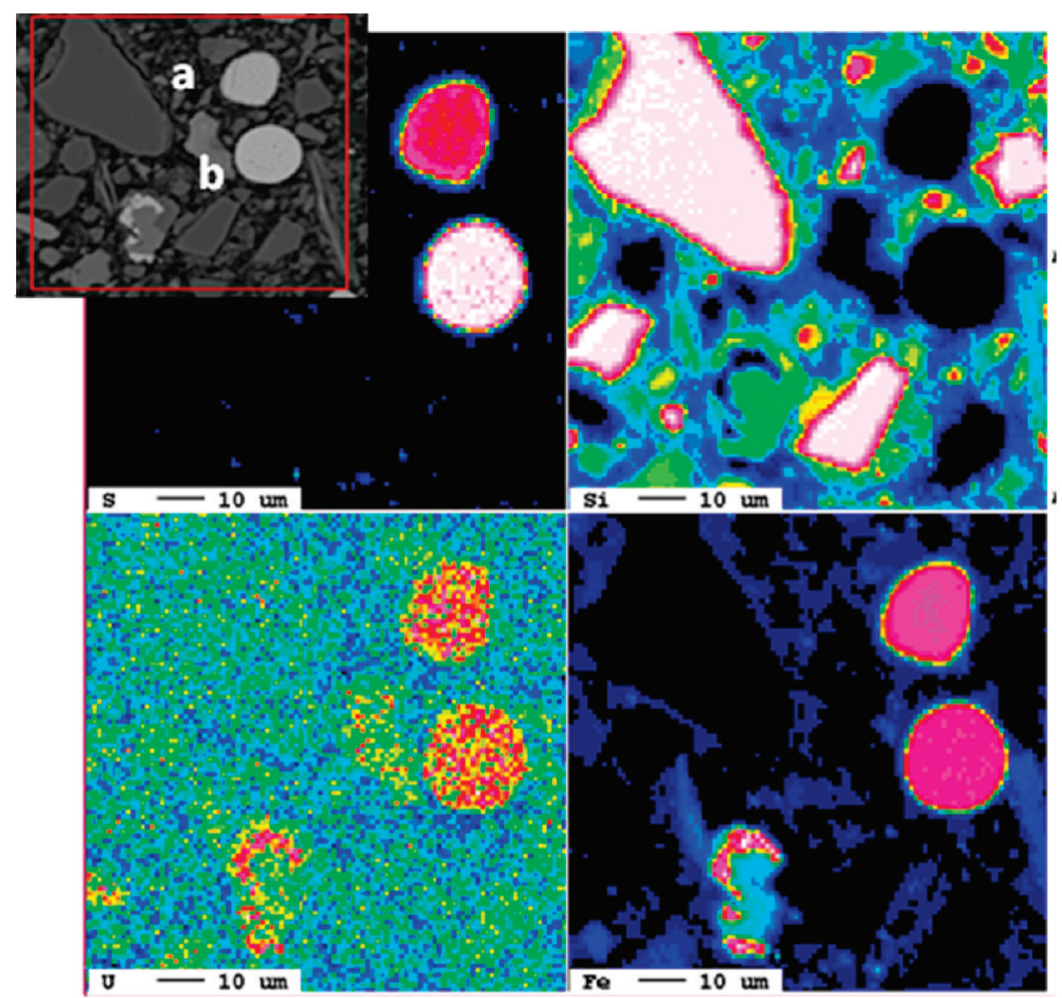

A.

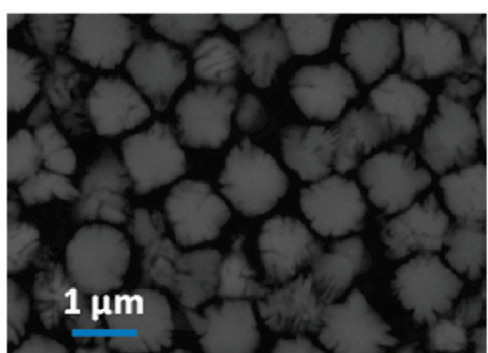

B.

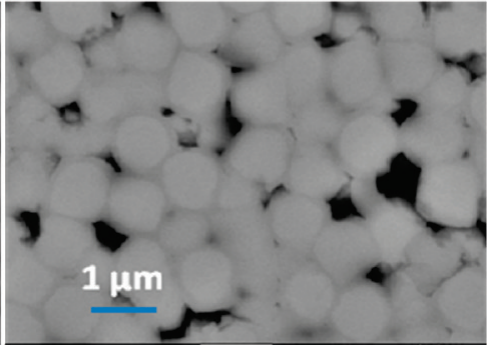

C.

FIGURE 3. Fe, S, U, and Si EMPA elemental mapping of the region depicted in the low magnification SEM backscattered image; high magnification SEM backscattered images of the surface of the two framboids (top framboid is weathered (left) and bottom framboid is unweathered (right)).

(Figure 3B and C). Extensive cracking, typical of surface corrosion, is evident in the weathered pyrite (Figure 3C). U is associated with both unweathered and weathered framboidal pyrites. This is an important finding because there are conflicting reports in the literature regarding the role played by the pyrite weathered products on U adsorption. For example, previous results showed that $U$ was mainly associated with the oxidized surface species of $S$ and Fe (26) (one should add here that in another study, S oxidation products were not observed but the authors suggested that Fe(III) compounds were present (27)). However, in another study, it was reported that freshly polished pyrite surfaces were efficient scavengers of $U$ from solution, while weathered surfaces exhibited only limited uptake (29).

The maximum $U$ concentration measured with EMPA was $0.840 \mu \mathrm{mol} \mathrm{g}^{-1}$ (later in the paper evidence will be presented for spots with higher U concentrations, up to $4.2 \mu \mathrm{mol} \mathrm{g}^{-1}$ ). The estimated values of the $U$ distribution coefficient $\left(K_{\mathrm{d}}\right)$ between framboidal pyrite and groundwater range from 56 to $764 \mathrm{~L} \mathrm{~kg}^{-1}$. This range was calculated assuming different $\mathrm{U}$ concentrations in groundwater, e.g., current groundwater concentration of $1.1 \mu \mathrm{mol} \mathrm{L^{-1 }}$ and the likely maximum groundwater concentration during $U$ milling operations of $15 \mu \mathrm{mol} \mathrm{L}{ }^{-1}$. Previous studies have not reported high $\mathrm{U}$ concentrations in framboidal pyrite. Conversely, one of the recent studies conducted with the shallow freshwater sediment of an open pit in an inactive $U$ mine, found that $U$ was not concentrated in framboidal pyrite (34). We infer that the pyrite examined by Suzuki et al. (2005) may have not formed in a high $U$ environment. Pyrite from the naturally bioreduced zones at Rifle, however, most likely formed during the maximum groundwater concentrations of $U$ at the site, commencing as early as 1924 when milling of vanadium began at the site including disposal of mill tailings containing significant $U$.

XRF, XANES, and EXAFS Analyses. The XRF maps of a sediment polished-section show a correlation between a strong Fe (Figure 4A) and U (Figure 4B) signal of a particle $\sim 10 \mu \mathrm{m}$ in size. The SEM micrographs taken at the same $U$ hot spot confirmed that this particle was framboidal pyrite (Figure 4D). U XANES and EXAFS spectra collected from the high-U region with approximately $1000 \mathrm{ppm} U(\sim 4.2 \mu \mathrm{mol}$ $\left.\mathrm{g}^{-1}\right)$, are shown in Figure $4 \mathrm{C}, \mathrm{E}$, and F. The U XANES spectrum shown in Figure $4 \mathrm{C}$ is consistent with a mixture of $\mathrm{U}(\mathrm{VI})$ and $\mathrm{U}(\mathrm{IV})$. The rise of the absorption edge is between the U(VI) and U(IV) standard, and there is a hint of the resonance feature above the absorption edge at approximately 17185 $\mathrm{eV}$. Additional XANES measurements were performed on $\mathrm{Fe}$ rich spots located throughout this sample (SI Figure S11 and S12). The $U$ in some of these spots is $90-100 \% \mathrm{U}(\mathrm{IV})$ (spots 

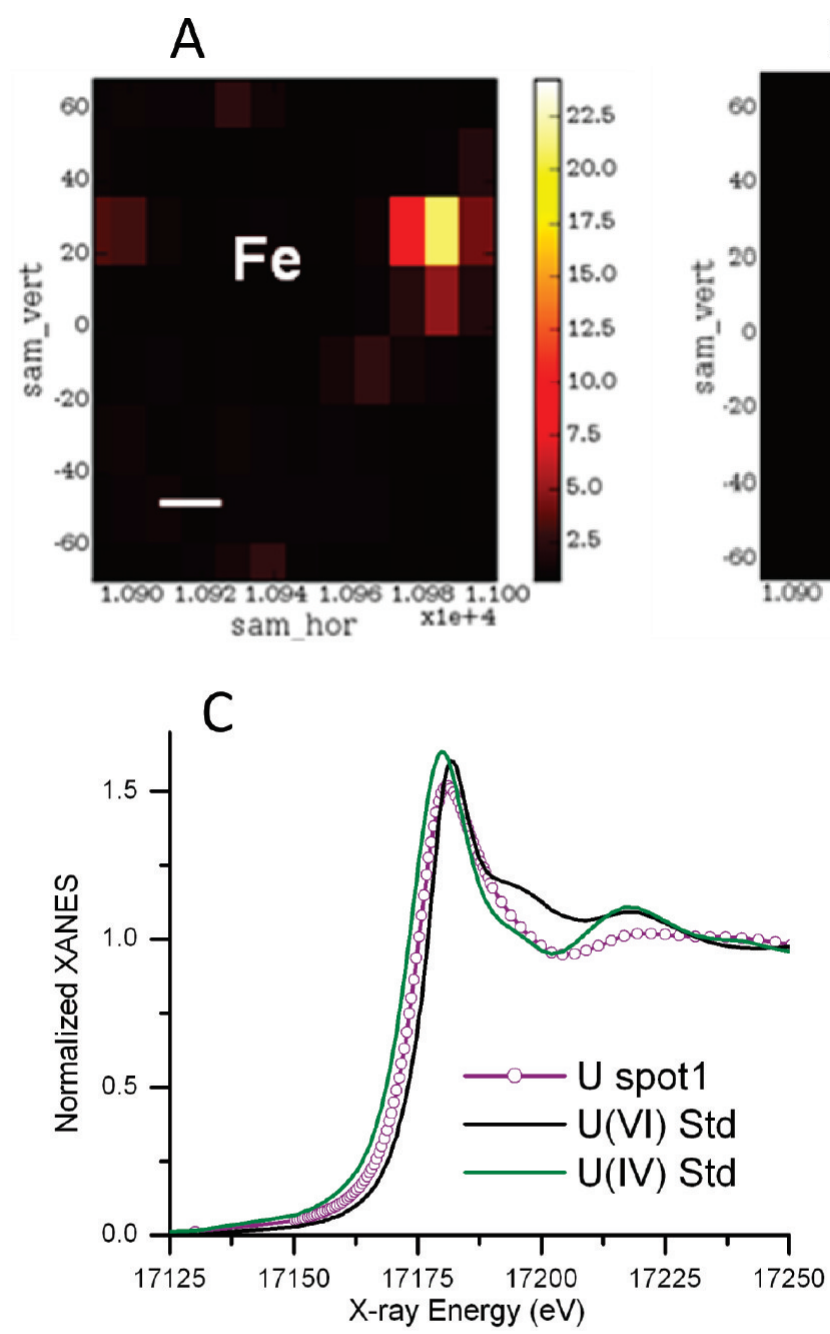

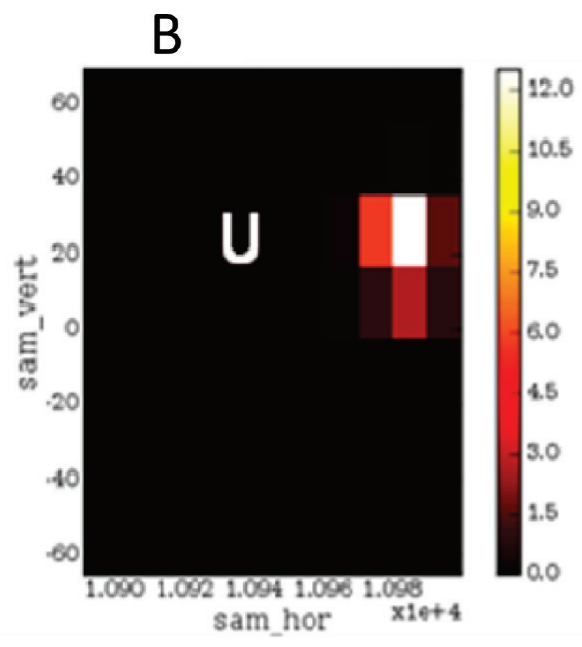

D

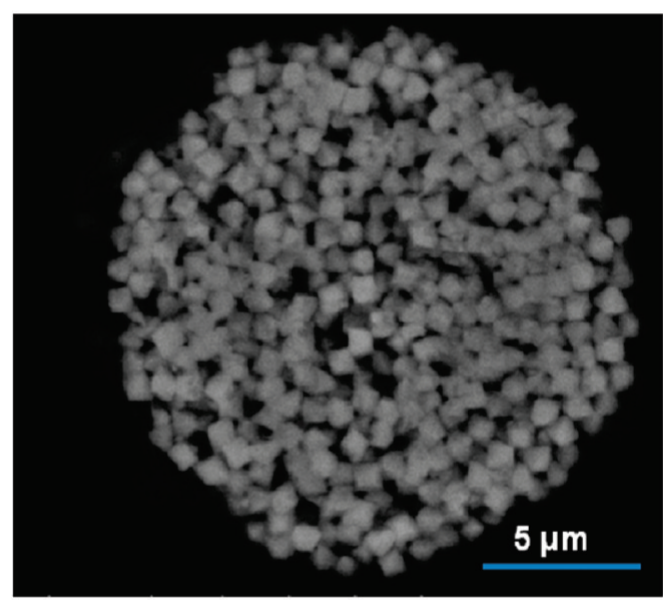

$E$

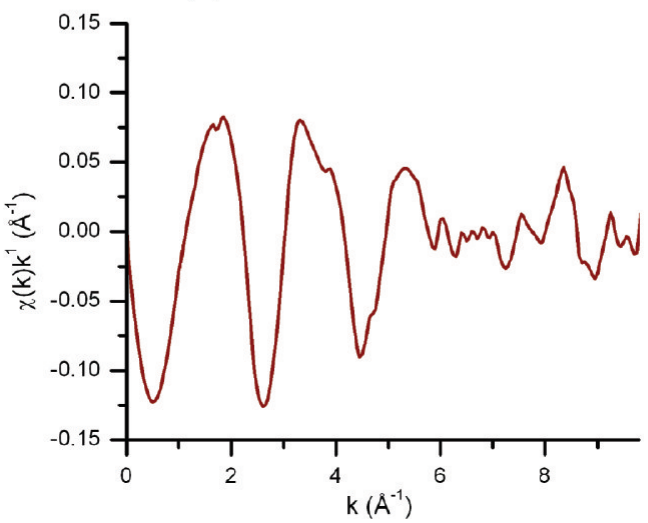

$\mathrm{F}$

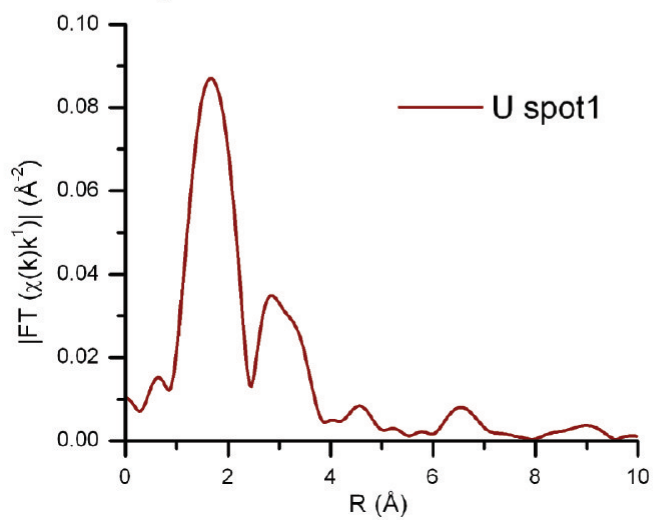

FIGURE 4. XRF elemental maps of Fe (A) and $U(B)$ (scale bar is $20 \mu \mathrm{m}$ ), and $U$ XANES (C) and EXAFS spectrum (E) and Fourier transform of EXAFS spectrum (F) collected in the naturally bioreduced sediment sample. SEM image of the framboidal pyrite of the high Fe and $U$ concentration spot 1 (D).

$\mathrm{x}, \mathrm{y}$, and $\mathrm{z}$ ), but there are other spots with a lower percentage of $\mathrm{U}(\mathrm{IV})$. A portion of $\mathrm{U}(\mathrm{VI})$ contributing to the XANES measurements may be from $U(V I)$ associated with the framboid surface and thus these measurements are perhaps not exclusively representative of the redox status of $U$ contained in framboid crystals.

The EXAFS spectra shown in Figure $4 \mathrm{E}$ and $\mathrm{F}$ illustrates a $U$ speciation that has a ligand beyond the first coordination sphere of oxygen due to the strong second shell signal. The Fourier transform shows the typical U-O signal at $1.8 \AA$ followed by another strong signal at $2.5-3.5 \AA$. It is this strong second-shell signal that is indicative of a structure around $\mathrm{U}$ atoms. It is clear that this second shell signal is not a $\mathrm{U}-\mathrm{U}$ structure typical of uraninite since this signal occurs at $3.80-3.87 \AA(35,36)$, since the atomic phase shift is small for $\mathrm{U}-\mathrm{U}$ pairs. Nor do we have the situation reported for bulk samples from a naturally bioreduced zone at Rifle where a second shell signal is completely absent, interpreted as indicating the presence of sorbed U(IV) (Kate Campbell, personal communication). While we have not been able to 
make a specific bond assignment to the second shell structure in Figure 4F, it likely indicates the structure that retains a reduced $\mathrm{U}-\mathrm{O}$ compound within the pyrite lattice. The signal in the Fourier transform between 2.5 and 3.5 A likely contains a contribution from multiple scattering of the axial oxygen atoms of the uranyl, although this signal will be suppressed by the U(IV) contribution which does not contain axial oxygen atoms. The signal could also arise from carbon and/or Fe ligands from the pyrite.

Framboidal Pyrite Formation. The age of formation of framboidal pyrites in the naturally bioreduced sediment of our study remains uncertain. The framboids were likely precipitated in the subsurface sediments after deposition because they are not present in the relatively oxidized sediments collected outside of the reduced zone (but only meters apart). The oxidized sediments exhibited general mineralogy similar to that of the bioreduced sediment.

Framboids usually have a spheroidal or subspheroidal outer form and are aggregates of discrete, equidimensional, and equimorphic microcrystals with a distinct internal microarchitecture (37). About 10 different framboids or framboid-like structures were depicted in a randomly selected area where the SEM micrograph of SI Figure S6 was taken. The framboids exhibited significant morphological differences and it was difficult to locate two framboids with identical morphological properties. Differences included size (i.e., outer diameter), microcrystal size, microcrystal shape, and microcrystal packing density (internal porosity). Previous work suggests that differences in framboid morphology could be related to the kinetics of formation (38). This morphological variability may also indicate that framboids were formed at different times or in different locations within the sediment matrix, and that the microenvironment conditions of formation may have had a pronounced effect on their morphological features.

Recent studies have demonstrated that framboidal pyrite is common in natural reduced systems. Examples include a shallow freshwater sediment of an inactive U mine where Fe and sulfate reduction had occurred (34), and in a permeable reactive barrier under $\mathrm{Fe}$ and sulfate reducing conditions (39). It is unclear why pyrite overwhelmingly, although not uniquely, forms framboidal structures with highly variable degree of self-organization without an obvious template (37). Theories proposed for the formation of framboidal pyrite range from biogenic, i.e., pyritic fossilization of bacterial colonies, to inorganic, based on laboratory syntheses over a range of thermal conditions (37). Four consecutive steps are proposed for the formation of framboid pyrite (40): (i) Nucleation and growth of initial monosulfide microcrystals; (ii) Conversion of these microcrystals to greigite $\left(\mathrm{Fe}_{3} \mathrm{~S}_{4}\right)$ (greigite is metastable with respect to pyrite); (iii) Aggregation of uniformly sized greigite microcrystals, i.e., framboid growth; and (iv) Replacement of greigite framboids by pyrite framboids. Results from other efforts have demonstrated that over time, mackinawite transforms readily to more stable Fe sulfide phases such as greigite through rearranging Fe atoms in a close-packed cubic array of S atoms (41). However, we did not find evidence for the presence of pyrite precursors (mackinawite or greigite) in our sample, based on Fe and S atomic ratios of $\mathrm{Fe}-\mathrm{S}$ rich regions. In a recent study conducted with a column packed with a blend of natural organic material, sand, and hematite, $54 \%$ of $\mathrm{FeS}$ was transformed to $\mathrm{FeS}_{2}$ (and framboidal pyrite) after only 2.4 years (39). Similar transformations almost certainly occurred in the naturally bioreduced sediment from Rifle.

Framboidal Pyrite: The Sink/Source Effect. Results from our study suggest that aqueous $U(V I)$ interacts with framboidal pyrite and adsorption and reduction of U(VI) could occur during this interaction. In addition, our results suggest that the concentration of $\mathrm{U}$ (most likely as $\mathrm{U}(\mathrm{VI})$ ) may further increase in framboidal pyrite because the secondary neophases formed during oxidation, such as Fe oxides, provide additional sorption sites to the system. Framboidal pyrite and associated secondary phases may, therefore, serve initially as a sink for aqueous U(VI). On the other hand, more complete oxidative dissolution of framboidal pyrite could subsequently increase both sorbed and aqueous U(VI) concentrations in this sediment. The naturally bioreduced zone could, therefore, serve as a net source of $U(V I)$ release to groundwater, making a significant contribution to sustaining the plume at the Rifle IFRC site.

Implications. The sulfide minerals present in naturally bioreduced sediments or formed during chemical treatments or biostimulation of the contaminated sites may play a significant role in controlling the mobility and migration of the redox-sensitive radionuclides, such as U(VI) by formation of relatively insoluble mineral phases containing high $U$ concentrations. Results from this study demonstrate that $U$ was concentrated in framboidal pyrite and that it was present as both $U(V I)$ and $U(I V)$. This is the first time that $U$ was found to be associated with framboidal pyrite in a Ucontaminated site. Results demonstrate that framboidal pyrites had physically, mineralogically, and chemically complex structures and surfaces. These structures may host $\mathrm{U}$ in energetically different sites or spatially different locations. Results also suggest that the concentration of $U$ may be increased in pyrite by initial oxidation. However, more complete subsequent oxidative dissolution of framboidal pyrite could make a significant contribution to sustaining the plume at the Rifle IFRC site and that the naturally bioreduced zone could therefore be a net source of $U$ released to groundwater in the future. Similary to sediments of oxidized subsurfaces (42), U desorption in naturally bioreduced sediments may exhibit strong time-dependency that is exacerbated by partially oxidized framboidal pyrite serving as long-term sources of $U$ contamination of groundwater. These results, together with the results from other research conducted with the sediments from the Rifle site, will provide the necessary scientific evidence to enhance the long-term in situ immobilization of $U$ with biostimulation strategies that mimic natural attenuation operating in suboxic alluvial aquifers.

\section{Acknowledgments}

N.P.Q. and R.K.K. contributed equally to this work. This research was supported by the U.S. Department of Energy (DOE), Office of Science, Environmental Remediation Sciences Program (ERSP), through the Integrated Field Research Challenge Site (IFRC) at Rifle, CO. Pacific Northwest National Laboratory is operated for the Department of Energy (DOE) by Battelle Memorial Institute under the Contract DE-AC0676RLO 1830. The research presented in this paper was conducted in part in the Environmental Molecular Sciences Laboratory, a national scientific user facility sponsored by the U.S. DOE Office of Biological and Environmental Research and located at the Pacific Northwest National Laboratory in Richland, WA. Use of the Advanced Photon Source (APS) at the Argonne National Laboratory is supported by the U.S. Department of Energy, Office of Science, Office of Basic Energy Sciences, under Contract DE-AC02-06CH11357. We acknowledge the contribution made by Soma Chattopadyay and Tomohiro Shibata to the EXAFS and XANES measurements made at APS, and Herbert T. Schaef (PNNL) for the XRD analysis.

\section{Supporting Information Available}

A detailed description of the methodology for sample collection and preservation, wet chemical extractions, Mössbauer spectroscopy, as well as additional experimental results. 
This material is available free of charge via the Internet at http://pubs.acs.org.

\section{Literature Cited}

(1) Riley, R. G.; Zachara, J. M.; Wobber, F. J. Chemical Contaminants on DOE Lands and Selection of Contaminant Mixtures for Subsurface Science Research; DOE/ER-0547T, DOE/ER-0547T; U.S. Department of Energy, Office of Energy Research: Washington, DC, 1992.

(2) Anderson, R. T.; Vrionis, H. A.; Ortiz-Bernad, I.; Resch, C. T.; Long, P. E.; Dayvault, R.; Karp, K.; Marutzky, S.; Metzler, D. R.; Peacock, A.; White, D. C.; Lowe, M.; Lovley, D. R. Stimulating the in situ activity of Geobacter species to remove uranium from the groundwater of a uranium-contaminated aquifer. Appl. Environ. Microbiol. 2003, 69 (10), 5884-5891.

(3) Vrionis, H. A.; Anderson, R. T.; Ortiz-Bernad, I.; O’Neill, K. R.; Resch, C. T.; Peacock, A. D.; Dayvault, R.; White, D. C.; Long, P. E.; Lovley, D. R. Microbiological and geochemical heterogeneity in an in situ uranium bioremediation field site. Appl. Environ. Microbiol. 2005, 71 (10), 6308-6318.

(4) Finneran, K. T.; Anderson, R. T.; Nevin, K. P.; Lovley, D. R. Potential for Bioremediation of uranium-contaminated aquifers with microbial U(VI) reduction. Soil Sed. Contam. 2002, 11 (3), 339-357.

(5) Finneran, K. T.; Housewright, M. E.; Lovley, D. R. Multiple influences of nitrate on uranium solubility during bioremediation of uranium-contaminated subsurface sediments. Environ. Microbiol. 2002, 4 (9), 510-516.

(6) Holmes, D. E.; Finneran, K. T.; O'Neil, R. A.; Lovley, D. R. Enrichment of members of the family Geobacteraceae associated with stimulation of dissimilatory metal reduction in uranium-contaminated aquifer sediments. Appl. Environ. Microbiol. 2002, 68 (5), 2300-2306.

(7) Komlos, J.; Moon, H. S.; Jaffe, P. R. Effect of sulfate on the simultaneous bioreduction of iron and uranium. J. Environ. Qual. 2008, 37 (6), 2058-2062.

(8) N'Guessan, A. L.; Vrionis, H. A.; Resch, C. T.; Long, P. E.; Lovley, D. R. Sustained removal of uranium from contaminated groundwater following stimulation of dissimilatory metal reduction. Environ. Sci. Technol. 2008, 42 (8), 2999-3004.

(9) Hua, B.; Deng, B. Reductive immobilization of uranium(VI) by amorphous iron sulfide. Environ. Sci. Technol. 2008, 42, 87038708.

(10) Campbell, K. M.; Qafoku, N. P.; Kukkadapu, R. K.; Peacock, A.; Lesher, E.; Figueroa, L.; Williams, K. H.; Wilkins, M. J.; Resch, C. T.; Davis, J. A.; Long, P. E., Characterizing the extent and role of natural subsurface bioreduction in a uranium-contaminated aquifer. Geochim. Cosmochim. Acta 2009, submitted.

(11) Qafoku, N. P.; Icenhower, J. P. Interaction of aqueous U(VI) with soil minerals in slightly alkaline natural systems. Rev. Environ. Sci. Biotechnol., 2008, 7, 355-380, DOI: 10.1007/s11157008-9137-8.

(12) Moyes, L. N.; Parkman, R. H.; Charnock, J. M.; Vaughan, D. J.; Livens, F. R.; Hughes, C. R.; Braithwaite, A. Uranium uptake from aqueous solution by interaction with goethite, lepidocrocite, muscovite, and mackinawite: An X-ray absorption spectroscopy study. Environ. Sci. Technol. 2000, 34, 1062-1068.

(13) Hsi, C. D.; Langmuir, D. Adsorption of uranyl onto ferric oxyhydroxides: Application of the surface complexation sitebinding model. Geochim. Cosmochim. Acta 1985, 49, 1931-1941.

(14) Ho, C. H.; Miller, N. H. Adsorption of uranyl species from bicarbonate solution onto hematite particles. J. Colloid Interface Sci. 1986, 110, 165-171.

(15) van Geen, A.; Robertson, A. P.; Leckie, J. O. Complexation of carbonate species at the goethite surface: Implications for adsorption of metal ions in natural waters. Geochim. Cosmochim. Acta 1994, 58, 2073-2086.

(16) Waite, T. D.; Davis, J. A.; Payne, T. E.; Waychunas, G. A.; Xu, N. Uranium(VI) adsorption to ferrihydrite: Application of a surface complexation model. Geochim. Cosmochim. Acta 1994, 58 (24), 5465-5478.

(17) Duff, M. C.; Amrhein, C. Uranium(VI) adsorption on goethite and soil in carbonate solutions. Soil Sci. Soc. Am. J. 1996, 60, $1393-1400$.

(18) Reich, T.; Moll, H.; Arnold, T.; Denecke, M. A.; Henning, C.; Geipel, G.; Bernhard, G.; Nitsche, H.; Allen, P. G.; Bucher, J. J.; Edelstein, N. M.; Shuh, D. K. An EXAFS study of uranium(VI) sorption onto silica gel and ferrihydrite. J. Electron Spectrosc. Relat. Phenom. 1998, 96 (1-3), 237-243.
(19) Bargar, J. R.; Reitmeyer, R.; Davis, J. A. Spectroscopic confirmation of uranium(VI)-carbonato adsorption complexes on hematite. Environ. Sci. Technol. 1999, 33 (10), 2481-2484.

(20) Villalobos, M.; Leckie, J. O. Surface complexation modeling and FTIR study of carbonate adsorption to goethite. J. Colloid Interface Sci. 2001, 235, 15-32.

(21) Dodge, C. J.; Francis, A. J.; Gillow, J. B.; Halada, G. P.; Eng, C.; Clayton, C. R. Association of uranium with iron oxides typically formed on corroding steel surfaces. Environ. Sci. Technol. 2002, 36, 3504-3511.

(22) Wazne, M.; Korfiatis, G. P.; Meng, X. G. Carbonate effects on hexavalent uranium adsorption by iron oxyhydroxide. Environ. Sci. Technol. 2003, 37, 3619-3624.

(23) Lefevre, G.; Noinville, S.; Fedoroff, M. Study of uranyl sorption onto hematite by in situ attenuated total reflection-infrared spectroscopy. J. Colloid Interface Sci. 2006, 296 (2), 608-613.

(24) Jang, J. H.; Dempsey, B. A.; Burgos, W. D. A model-based evaluation of sorptive reactivities of hydrous ferric oxide and hematite for U(VI). Environ. Sci. Technol. 2007, 41 (12), 43054310.

(25) Rovira, M.; El Aamrani, S.; Duro, L.; Gimenez, J.; de Pablo, J.; Bruno, J. Interaction of uranium with in situ anoxically generated magnetite on steel. J. Hazard. Mater. 2007, 147 (3), 726-731.

(26) Wersin, P.; Hochella, M. F.; Persson, P.; Redden, G.; Leckie, J. O.; Harris, D. W. Interactions between aqueous uranium(VI) and sulfide minerals-Spectroscopic evidence for sorption and reduction. Geochim. Cosmochim. Acta 1994, 58 (13), 2829-2843.

(27) Eglizaud, N.; Miserque, F.; Simoni, E.; Schlegel, M.; Descostes, M. Uranium(VI) interaction with pyrite $\left(\mathrm{FeS}_{2}\right)$ : Chemical and spectroscopic studies. Radiochim. Acta 2006, 94 (9-11), 651656.

(28) Aubriet, H.; Humbert, B.; Perdicakis, M. Interaction of U(VI) with pyrite, galena and their mixtures: a theoretical and multitechnique approach. Radiochim. Acta 2006, 94 (9-11), $657-663$.

(29) Scott, T. B.; Tort, O. R.; Allen, G. C. Aqueous uptake of uranium onto pyrite surfaces; reactivity of fresh versus weathered material. Geochim. Cosmochim. Acta 2007, 71 (21), 5044-5053.

(30) Segre, C. U.; Leyarovska, N. E.; Chapman, L. D.; Lavender, W. M.; Plag, P. W.; King, A. S.; Kropf, A. J.; Bunker, B. A.; Kemner, K. M.; Dutta, P.; Druan, R. S.; Kaduk, J. The MRCAT insertion device beamline at the Advanced Photon Source. Synchrotron Rad. Inst. 2000, CP521, 419-422.

(31) Cross, J. O.; Frenkel, A. I. Use of scattered radiation for absolute energy calibration. Rev. Sci. Instrum. 1998, 70, 38-40.

(32) Newville, M. IFEFFIT: Interactive EXAFS analysis and FEFF fitting. J. Synchrotron. Radiat. 2001, 8, 322-324.

(33) Ravel, B.; Newville, M. ATHENA, ARTEMIS, HEPHAESTUS: Data analysis for X-ray absorption spectroscopy using IFEFFIT. $J$. Synchrotron. Radiat. 2005, 12 (4), 537-541.

(34) Suzuki, Y.; Kelly, S. D.; Kemner, K. M.; Banfield, J. F. Direct microbial reduction and subsequent preservation of uranium in natural near-surface sediment. Appl.Environ. Microbiol. 2005, 71 (4), 1790-1797.

(35) Schofield, E. J.; Veeramani, H.; Sharp, J. O.; Suvorova, E.; BernierLatmani, R.; Mehta, A.; Stahlman, J.; Webb, S. M.; Clark, D. L.; Conradson, S. D.; Ilton, E. S.; Bargar, J. R. Structure of Biogenic Uraninite Produced by Shewanella oneidensis Strain MR-1. Environ. Sci. Technol. 2008, 42 (21), 7898-7904.

(36) Singer, D. M.; Farges, F.; Brown Jr, G. E. Biogenic nanoparticulate $\mathrm{UO}_{2}$ : Synthesis, characterization, and factors affecting surface reactivity. Geochim. Cosmochim. Acta 2009, 73 (12), 3593-3611.

(37) Ohfuji, H.; Rickard, D. Experimental syntheses of framboids-A review. Earth-Science Reviews 2005, 71 (3-4), 147-170.

(38) Butler, I. B.; Rickard, D. Framboidal pyrite formation via the oxidation of iron (II) monosulfide by hydrogen sulphide. Geochim. Cosmochim. Acta 2000, 64 (15), 2665-2672.

(39) He, Y. T.; Wilson, J. T.; Wilkin, R. T. Transformation of reactive iron minerals in a permeable reactive barrier (biowall) used to treat TCE in groundwater. Environ. Sci. Technol. 2008, 42 (17), 6690-6696.

(40) Wilkin, R. T.; Barnes, H. L. Formation processes of framboidal pyrite. Geochim. Cosmochim. Acta 1997, 61 (2), 323-339.

(41) Posfai, M.; Buseck, P. R.; Bazylinski, D. A.; Frankel, R. B. Reaction sequence of iron sulfide minerals in bacteria and their use as biomarkers. Science 1998, 280 (5365), 880-883.

(42) Qafoku, N. P.; Zachara, J. M.; Liu, C.; Gassman, P. L.; Qafoku, O. S.; Smith, S. C. Kinetic desorption and sorption of U(VI) during reactive transport in a contaminated Hanford sediment. Environ. Sci. Technol. 2005, 39, 3157-3165.

ES9017333 